\title{
Analisa Gaya Kepemimpinan Direktur Utama PT IMSC (Inka Multi Solusi Consulting)
}

\author{
Danik Karyawati \\ ${ }^{1}$ Program Studi Manajemen Keuangan, Akademi Manajemen Koperasi Tantular Madiun, Jl.Mayjend Panjaitan, Madiun, 63137 \\ E-mail: dhanik.karyawati@gmail.com
}

\begin{abstract}
Dalam suatu organisasi tentunya diperlukan adanya hirarki pimpinan dan bawahan. Oleh karena itu sangat perlu sumberdaya manusia yang berkualitas untuk menjadi pimpinan dan bawahan. Penelitian ini bertujuan untuk menganalisis apa jenis gaya kepemimpinan yang dilakukan atau diterapkan oleh Direktur Utama pada PT. IMSC. Metode penelitian ini adalah metode kualitatif melalui wawancara untuk memperoleh data dari ketiga informan. Uji keabsahan data ketiga informan menggunakan metode triangulasi sumber. Hasil dari penelitian ini membuktikan gaya kepemimpinan yang diterapkan oleh direktur di PT. IMSC didominasi oleh gaya kepemimpinan Supportif dan Partisipasif, tetapi dalam situasi tertentu direktur juga menggunakan gaya kepemimpinan Direktif.
\end{abstract}

Keywords_: Gaya Kepemimpinan Kepemimpinan Supportif; Gaya Kepemimpinan Partisipasif; Gaya Kepemimpinan Direktif.

\section{PENDAHULUAN}

\section{A. Latar Belakang Masalah}

Organisasi merupakan suatu wadah bagi orang-orang untuk berkumpul dan bekerja sama untuk mencapai tujuan bersama. Sedangkan sumberdaya manusia adalah tenaga yang berpotensi dan tidak dapat dipisahkan dari organisasi atau unit kerja. Dalam hubungan dengan organisasi dan unit kerja ini penulis tertarik untuk meneliti PT IMSC (INKA Multi Solusi Consulting) yang merupakan salah satu Perusahaan afiliasi dari PT INKA Madiun yang bergerak dalam bidang jasa konsultan yang didalamnya meliputi konsultan bidang pengawasan, inspeksi, teknologi perkeretaapian, perencanaan infrastruktur, manajemen konstruksi, Feasibility Study dan lain- lain . Perkembangan usaha di IMSC secara umum dinilai mengalami percepatan, mengingat berdirinya masih berumur satu tahun yaitu di awal tahun 2017, namun pekerjaan penggarapan proyek konsultan ini dinilai memberikan dorongan positif bagi salah satu perusahaan konsultan di Indonesia ini untuk semakin mengembangkan usahanya. Hal ini diperkuat oleh pernyataan Direktur Utama PT INKA Budi Noviantoro sebagai pembina induk dari PT IMSC, bahwa "Dengan keaktifan dalam kancah bisnis konsultan di Ekonomi Global ini, maka PT IMSC akan menjadi perusahaan yang besar". Berdasarkan data, pendapatan jasa tahun pertama 3,5 Milyard dan memasuki tahun ke dua diakhir tahun 2018 naik drastis mencapai 12,5M. Dan pada tahun kedua tersebut IMSC telah memasuki pasar global dengan terbukti menjadi inspektor mesin korea. Disamping hal tersebut PT IMSC memperkuat penetrasi pasar jasa dalam negeri seperti, menjadi pengawas pekerjaan Rest Area jalan Tol yang terkonsesi oleh PT ASTRA Infra Tol, menjadi pelaksana study kelayakan investasi PT Antam Tbk, melalui proses tender Internasional. Ke depan PT IMSC mentargetkan untuk memasuki jasa konsultan ke luar negeri yang lebih luas seperti Filiphina, Thailand, Bangladesh berdampingan dengan induk perusahaan PT INKA.

Dalam proses bisnis internalnya PT IMSC mentargetkan mendapatkan sertifikasi internasional seperti ISO 9000 agar memiliki kompetensi yang diakui dunia untuk meningkatkan layanan terhadap seluruh costumernya serta memperkuat sinergi bisnis dengan perusahaan-perusahaan sejenis baik didalam maupun luar negeri. Yang saat ini menjadi focus dalam negeri seperti berpatner dengan BUMN besar untuk memperoleh konsultasi operating dan maintenance services jangka panjang terhadap prasarana perkeretaapian diluar pulau jawa, adapun diluar negeri sedang merintis partnership dalam bidang konsultasi dan studi Dryport di Filiphina utara.

Dengan perkembangan dan peningkatan eksistensi perusahaan tersebut, maka PT IMSC berupaya meningkatkan kompetensi serta kualitas pelayanan jasa sebagai konsultan dan berkomitmen untuk mewujudkan visi dan misinya sebagai perusahaan konsultan yang professional di dunia internasional. Hal tersebut tidak terlepas dari pola manajerial intern perusahaan, terutama peran kepemimpinan yang secara langsung atau tidak langsung berhubungan dengan karyawan yang dipimpinnya. Peran seorang pemimpin sangatlah penting dalam memberikan semangat dan motivasi serta menciptakan suasana kerja yang kondusif dan harmonis untuk mencapai tujuan perusahaan.

Peran seorang pemimpin dalam mempengaruhi bawahannya sangatlah penting bagi kemajuan organisasi tersebut. Daft (2011) menjelaskan bahwa kepemimpinan sebagai hubungan saling mempengaruhi antara para pemimpin dan para pengikut dimana mereka ingin membuat perubahan yang nyata demi mencerminkan tujuan bersama. Pemimpin biasanya menerapkan gaya kepemimpinan tertentu untuk mempengaruhi kinerja bawahannya. Gaya kepemimpinan merupakan perilaku pemimpin yang digunakan seseorang ketika ingin mempengaruhi orang lain. Sehubungan dengan hal tersebut maka penulis meneliti dan mengamati gaya kepemimpinan yang diterapkan pada PT IMSC. 
Website : http://ekomaks.unmermadiun.ac.id/index.php/ekomaks

\section{B. Tujuan Penelitian}

Tujuan penelitian Berdasarkan rumusan masalah yang ada, maka tujuan penelitian ini adalah : melakukan penelitian dan pengamatan yaitu mengidentifikasikan serta menganalisa gaya kepemimpinan yang diterapkan direktur di PT. IMSC

\section{Manfaat Penelitian}

Manfaat dari penelitian ini yang utama adalah menambah pengetahuan khususnya bagi penulis pribadi dan para pengguna informasi pada umumnya bagaimana peran pentingnya Manajemen Sumber Daya Manusia dalam suatu Perusahaan. Karena tidak sedikit kegagalan perusahaan disebabkan karena gaya kepemimpinan yang salah, maka penelitian ini diharapkan dapat bermanfaat bagi manajemen perusahaan khususnya bagi pimpinan perusahaan agar bisa menjadi informasi dan pengetahuan ataupun bahan acuan dalam menerapkan pola kepemimpinannya dalam mencapai tujuan perusahaan dan meminimalisir kegagalan.

\section{Metodologi Penelitian}

Penelitian ini menggunakan metode kualitatif. Menurut Sugiyono (2012), kualitatif adalah penelitian yang menggunakan analisis data dengan cara mendeskripsikan atau menggambarkan data yang sudah terkumpul. Salah satu ciri penelitian kualitatif adalah deskriptif. Menurut Maleong (2013 hal.11) ciri dari deskriptif yaitu data yang dikumpulkan adalah berupa kata-kata, gambar dan bukan angka-angka. Data tersebut mungkin dari naskah wawancara, catatan lapangan, foto atau videotape, dokumen pribadi catatan atau memo dan dokumen resmi lainya. Dengan ini, peneliti memilih jenis penelitian kualitatif guna untuk mengetahui gaya kepemimpinan apa yang digunakan Direktur Utama PT IMSC.

Metode pengumpulan data dalam penelitian ini dilakukan melalui wawancara dan dokumen. Wawancara menurut esterberg (dalam Sugiono, 2012, hal 410) adalah pertemuan dua orang untuk bertukar informasi dan ide melalui tanya jawab, sehingga dapat dikonstruksikan makna dalam suatu topik tertentu Jenis wawancara yang digunakan adalah wawancara semistruktur. Tujuan penggunaan wawancara semiterstruktur ini adalah untuk menemukan permasalahan yang lebih terbuka agar dapat menggali data lebih mendalam dimana pihak yang diwawancarai juga diminta pendapat atau ide-idenya, sehingga penulis akan mendengarkan secara teliti dan seksama apa yang dikemukakan oleh narasumber.

Metode penelitian kedua adalah dokumentasi, dimana peneliti menggunakan dokumen-dokumen yang merupakan catatan peristiwa yang telah berlalu. Dokumen yang akan digunakan dalam penelitian ini antara lain adalah struktur organisasi, job description, dan dokumentasi hasil pencapaian kerja perusahaan. Dalam proses analisis data, peneliti menggunakan definisi dari Sugiyono (2012) dimana analisis data terdiri dari proses mereduksi data, menyajikan data, dan membuat kesimpulan. Dalam menguji keabsahan data, peneliti menggunakan teknik triangulasi sumber dimana triangulasi yang digunakan dalam penelitian ini adalah triangulasi sumber yaitu menguji kredibilitas data dilakukan dengan cara mengecek data yang diperoleh melalui berberapa sumber. Kemudian dideskripsikan, dikategorikan mana pandangan yang sama, yang berbeda dan mana spesifik dari tiga sumber data tersebut kemudian dijadikan suatu kesimpulan.

\section{TINJAUAN PUSTAKA}

\section{A. Peranan dan Pengertian Pemimpin}

Peranan sosok pemimpin berpengaruh bagi karyawan. Karyawan merupakan salah satu bentuk aset internal yang paling berharga yang dimiliki oleh perusahaan. Irham Fahmi (2012:100). Artinya dengan kebijakan dan usaha kuat untuk selalu menjaga dan mempertahankan karyawan maka diharapkan akan mampu menghindari faktor-faktor yang mengakibatkan tidak tercapainya tujuan organisasi. Dalam suatu organisasi fungsi dan peran pemimpin dalam mendorong pembentukan organisasi diharapkan menjadi dominan.

Pada era globalisasi kepemimpinan yang dibutuhkan adalah yang memiliki nilai kompetensi yang tinggi,dan potensi itubiasa diperoleh jika pemimpin tersebut telah memiliki Experience (pengalaman),science(ilmu pengetahuan) yang maksimal.Persoalan semua ini baru akan terjadi dalam waktu panjang,dan sifatnya berotasi. Ini sebagaimana dikatakan oleh Andreas Harefa, dalam buku Irham Fahmi, (2012: 99) bahwa "penguasa berkomptensi baru akan terjadi jika pemimpin mengalami proses rotasi untuk mengerjakan tugas yang berbeda sehingga ia terus belajar". Rotasi ini dapat terjadi dalam bentuk pemindahan tugas dari satu tempat ketempat lainnya. Lebih jauh pemimpin harus memahami kepemilikan karakteristik karyawannya.

Menurut Henry Pratt Fairchild (dalam Kartono 2010:23), pemimpin adalah seorang yang memimpin dengan jalan memprakarsai tingkah laku sosial dengan mengatur, mengarahkan, mengorganisir atau mengontrol usaha/upaya orang lain atau melalui kekuasaan dan posisi.

Berdasarkan konsep dan teori yang telah dikemukakan diatas, dapat disimpulkan bahwa pemimpin adalah seseorang yang memiliki kemampuan untuk mengarahkan bawahannya untuk mencapai tujuan organisasi. Upaya untuk menilai sukses atau gagalnya pemimpin itu antara lain dilakukan dengan mengamati dan mencatat sifat-sifat dan kualitas perilakunya, yang dipakai sebagai kriteria untuk menilai kepemimpinannya.

\section{B. Kriteria yang harus di miliki seorang Pemimpin}

Menurut George R. Terry dalam bukunya "Principles of Management" dikutip oleh Kartono (2010:47) menuliskan sifat pemimpin yang unggul, yaitu : 
Website : http://ekomaks.unmermadiun.ac.id/index.php/ekomaks

a. Kekuatan

Kekuatan badaniah dan rohaniah merupakan syarat pokok bagi pemimpin yang bekerja lama dan berat pada waktu-waktu yang tidak teratur, dan ditengah situasi yang sering tidak menentu. Oleh karena itu daya tahan merupakan syarat yang harus dimiliki seorang pemimpin.

b. Stabilitas Emosi

Pemimpin yang baik memiliki emosi yang stabil, artinya tidak mudah marah, tersinggung perasaan, dan tidak meledak-ledak emosinya. Dia menghormati martabat orang lain, toleran terhadap kelemahan orang lain, bisa memaafkan kesalahan yang tidak terlalu prinsipil. Semua itu diarahkan untuk mencapai lingkungan sosial yang rukun, harmonis, damai dan menyenangkan.

c. Pengetahuan Tentang Relasi Insani

Seorang pemimpin harus bisa memajukan dan mengembangkan semua bakat dan potensi bawahan untuk bersama-sama maju dan mengecap kesejahteraan. Karena itu pemimpin memiliki pengetahuan tentang sifat, watak dan perilaku anggota kelompoknya.

d. Kejujuran

Pemimpin yang baik mempunyai kejujuran, yaitu jujur pada diri sendiri atau orang lain. Dia selalu menepati janji, dapat dipercaya dan berlaku adil terhadap semua orang.

e. Obyektif

Pertimbangan pemimpin harus obyektif dan memberikan alasan yang rasional dalam pengambilan keputusan.

f. Dorongan Pribadi

Pemimpin harus mempunyai motivasi dalam dirinya untuk menjadi pemimpin adapun dukungan dari luar hanya untuk memperkuat dalam memberikan pelayanan dan pengabdian kepada kepentingan orang banyak.

g. Keterampilan Komunikasi

Seorang pemimpin dituntut harus pandai dalam berkomunikasi dengan semua orang, dan pandai mengintegrasikan berbagai opini dan aliran yang berbeda untuk mencapai kerukunan dan keseimbangan.

h. Kemampuan Mengajar

Diharapkan pemimpin bisa membawa orang disekitarnya secara sistematis dan intensional pada sasaran tertentu guna mengembangkan pengetahuan, menambah pengalaman yang diharapkan dapat mandiri, mau memberikan loyalitas dan partisipasinya.

g. Keterampilan Sosial

Pemimpin harus memiliki kemampuan mengelola sumber daya manusia, agar mereka dapat mengembangkan bakat dan potensinya serta menjadi motivator bawahannya.

i. Kecakapan teknis/ Manajerial

Pemimpin adalah seorang manajer yang harus bisa merencanakan, mengelola, menganalisa, membuat keputusan, mengarahkan dan mengontrol kegiatan dalam organisasi.

Pemimpin biasanya menerapkan gaya kepemimpinan tertentu untuk mempengaruhi seseorang ketika ingin mempengaruhi orang lain. Menurut Hughes, Ginnet \& Curphy (2012) gaya kepemimpinan adalah perilaku yang menggabungkan pengetahuan, seni, rasionalitas, dan emosional untuk bias mempengaruhi orang lain.

Ada bermacam-macam gaya kepemimpinan menurut House Robbins, dalam Suwatno (2013:158), yaitu:

1) Directive Leadership - Gaya Direktif

Pemimpin yang memusatkan kuasa dan pengambilan keputusan bagi dirinya sendiri, pemimpin berwenang penuh dan memikul tanggung jawab sepenuhnya. Tipe ini merupakan praktek kepemimpinan otoriter, anggota atau bawahan tidak pernah berkesempatan untuk berpartisipasi dalam mengemukanan pendapat, apalagi dalam pengambilan keputusan gaya seperti ini didasarkan pada penggunaaan kekuatan, kekuasaan dan wewenang memberikan petunjuk spesifik untuk kinerja bawahannya.

Pemimpin tipe ini menganggap kepemimpinannya merupakan hak pribadinya dan berpendapat bahwa ia dapat menentukan apa saja dalam organisasi, tanpa mengadakan konsultasi dengan bawahan - bawahannya yang melaksanakan. Pelaksanaan yang sangat tegang pula, sehingga lebih tepat apabila kepemimpinanan atau pemimpin tipe ini dimanfaatkan oleh keadaan darurat, dimana suatu konsultasi dengan bawahan sudah tidak mungkin lagi.

Pemimpin pengarah cenderung untuk :

a) Menetapkan pelaksanaan tujuan kelompok.

b) Menetapkan tanggung jawab bagi pelaksanaan.

c) Membentuk saluran komando yang pasti.

d) Melatih pegawai untuk melaksanakan tugas.

e) Memberikan informasi dan instruksi yang diperlukan.

f) Menggunakan imbalan dan hukuman untuk mengontrol perilaku bawahan.

g) Menetapkan hubungan prestasi - imbalan.

2) Supportive Leadership - Gaya Suportif

Gaya kepemimpinan bersifat ramah dan menunjukkan kepedulian dan perhatian kepada bawahannya

Pemimpin cenderung untuk : 
Website : http://ekomaks.unmermadiun.ac.id/index.php/ekomaks

a) Menunjukkan perhatian pribadi pada bawahan.

b) Bersahabat dan mudah ditemui.

c) Mengadakan terus menerus konsultasi pribadi.

d) Mendorong bawahan untuk memperliatkan perasaan dan perhatian.

e) Berusaha membuat keselarasan dalam kelompok kerja.

f) Menggunakan imbalan sebagai alat memperoleh dukungan.

g) Lebih banyak menggunakan imbalan positif dari pada sanksi negatif.

3) Partisipative Leadership - Gaya Partisipatif

Gaya Kepemimpinan yang meminta dan menggunakan saran - saran bawahan dalam rangka mengambil keputusan. Dengan demikian bawahannya merasa lebih dihargai oleh atasannya karena mereka dianggap mampu berperan dalam pengambilan keputusan. Dengan gaya kepemimpinan seperti ini, hubungan antara pemimpin dengan bawahan akan terjaga dengan baik. Pemimpin cenderung untuk :

a) Mengizinkan kelompok menetapkan pelaksanaan tujuan mereka sendiri.

b) Mengizinkan anggota kelompok menyusun pekerjaan mereka sendiri.

c) Mengatasi perbedaan atau kesulitan dengan bawahan.

d) Menggunakan peran serta bawahan sebagai alat komunikasi.

e) Memperbolehkan anggota kelompok menjalankan kontrol atas kemajuan prestasi.

f) Lebih banyak menggunakan system imbalan berdasarkan kelompok dari pada individu

g) Sama - sama menanggung keberhasilan dan kegagalan kelompok dengan bawahan.

4) Achievement-Oriented Leadership - Kepemimpinan Orientasi Prestasi.

Kepemimpinan yang berorientasi pada hasil gaya kepemimpinan ini, pemimpin memberi tantangan kepada pengikut dengan standar pekerja yang tinggi, serta melakukan perbaikan terus-menerus.

\section{Pengaruh Gaya Kepemimpinan Terhadap Kinerja Karyawan}

Menurut Wilson Bangun (2012:231) pengertian kinerja adalah, sebagai berikut :"Kinerja (performance) adalah hasil pekerjaan yang dicapai seseorang berdasarkan persyaratan-persyaratan pekerjaan (job requirement)."

Thoha (2010, h.42), mengungkapkan bahwa dengan mempergunakan kepemimpinan maka pemimpin akan mempengaruhi persepsi bawahan dan memotivasinya, dengan cara mengarahkan karyawan pada kejelasan tugas, pencapaian tujuan, kepuasan kerja, dan pelaksanaan kerja yang efektif

\section{Hubungan Gaya Kepemimpinan dan Kinerja Karyawan}

Salah satu cara untuk mengetahui suatu kepemimpinan berhasil adalah dengan mengetahui seberapa tinggi prestasi yang dapat dicapai oleh organisasi yang dipimpinnya. Oleh karenanya dibutuhkan seorang pemimpin yang dapat mengetahui para karyawannya untuk bekerja secara efektif demi tercapainya tujuan organisasi serta mampu berkomunikasi dengan baik antar sesama karyawan dapat tercipta jalinan kerja yang harmonis.

Asas-asas kepemimpinan yang baik itu seharusnya berlandaskan; kemanusiaan, yaitu berupa pemberian tuntunan untuk mengembangkan semua potensi individu, Efisiensi teknis, efisiensi sosial dan asa manajemen modern, kesejahteraan serta kebahagian insani yang lebih merata. Menurut Amirullah (2015 : 167 ), Kepemimpinan adalah orang yang memiliki wewenang untuk memberi tugas, mempunyai kemampuan untuk membujuk atau mempengaruhi orang lain dengan melalui pola hubungan yang baik guna mencapai tujuan yang telah di tentukan. Jika dikaitkan dengan kinerja, maka ketika pimpinan menetapkan tujuan yang ingin dicapai adalah peningkatan kinerja, maka pimpinan akan menggunakan kepemimpinannya untuk mengendalikan bawahannya agar mengarah pada peningkatan kinerja. Sebagai hasilnya, melalui kepemimpinan yang baik maka organisasi akan berhasil mencapai target kinerja sesauai yang diharapkan.

Dari pengertian dan rumusan diatas maka dapat disimpulkan bahwa pengaruh gaya kepemimpinan terhadap kinerja karyawan begitu besarnya karena pada dasarnya gaya kepemimpinn adalah kemampuan untuk mempengaruhi dan mengarahkan orang lain agar lebih giat dalam bekerja demi tercapainya suatu tujuan organisasi.

Singkatnya, bahwa dengan adanya pengaruh gaya kepemimpinan terhadap kinerja karyawan, maka akan dicapai peningkatan kemampuan (ability) karyawan, motivasi, kualitas supervisi (kepemimpinan) dan sikap karyawan terhadap tugas yang pada gilirannya dapat menunjang peningkatan kinerja, sehingga daptalah dikatakan bahwa terdapat keterkaitan antara gaya kepemimpinan dan kinerja karyawan.

\section{III.HASIL PENELITIAN DAN PEMBAHASAN}

\section{A. Gambaran Umum Perusahaan}

PT. IMSC (Inka Multi Solusi Consulting) berdiri sejak Tanggal 23 Maret Tahun 2017. Perusahaan ini merupakan salah satu Anak PT INKA Multi Solusi yang bergerak dalam bidang jasa konsultasi rancang bangun, perekayasaan, distributor dan pemeliharaan/berteknologi tinggi di bidang perkeretaapian dan transportasi darat lainnya. IMSC berlokasi di Jalan Salak no 23, Taman, Kota Madiun, Jawa Timur. Perusahaan ini berdiri atas inisiatif dari bapak Direktur Keuangan INKA saat itu yaitu bapak Nursodiq yang berharap PT IMSC di masa depan mampu menjadi perusahaan yang berkembang dan dapat memperluas 
Website : http://ekomaks.unmermadiun.ac.id/index.php/ekomaks

cakupan target pasarnya, khususnya untuk penetrasi pasar domestik dan pengembangan pasar manufaktur perkeretaapian dan transportasi darat bertaraf internasional.

\section{B. Visi Misi PT IMSC}

Adapun Visi perusahaan IMSC adalah “ Menjadi perusahaan yang unggul dalam bidang project managemen, design engineering dan design manufaktur di indonesia, yang memiliki daya saing global di bidang sarana dan prasarana perkeretaapian dan transportasi"

Sedangkan misi dari IMSC adalah " Menciptakan dan memberikan solusi yang terbaik dengan pemanfaatan teknologi tepat guna dalam mendukung pengembangan teknologi sarana dan prasarana perkeretaapian dan transportasi"

Seperti yang telah dijelaskan sebelumnya bahwa metode pengumpulan data dalam penelitian ini dilakukan melalui wawancara dan dokumen. Adapun dokumen pendukungnya adalah struktur organisasi, job descrebtion, serta beberapa gambar pendukung hasil pencapaian kerja perusahaan. (Terlampir). Berikut ini adalah beberapa data yang terkumpul dan hasil wawancara dari ke 3 informan:

\section{Profil Informan}

Profil Informan pada penelitian ini adalah:

- Informan 1

Nama : Mochammad Wildan

Usia : 28 tahun

Bagian : Jasa Perkeretaapian

- Informan 2

Nama : Ayuvi Maya Putri

Usia : 30 tahun Jabatan

Bagian : Staff umum

- Informan 3

Nama : Nur Cholis

Usia : 37 tahun

Bagian : Tenaga ahli

Peneliti menganalisis gaya kepemimpinan yang diterapkan oleh direktur utama PT IMSC dengan berdasarkan beberapa indikator. Menurut Hasibuan (2012, p.170) indikator dalam gaya kepemimpinan yaitu pendelegasian wewenang, sifat pemimpin, pengambilan keputusan dan kebijakan dan pengarahan bawahan. Berikut adalah data hasil wawancara ke 3 informan ditinjau dari beberapa indikator diatas :

1. Dari segi pendelegasian wewenang :

a. Informan 1 : Pemimpin mendorong saya untuk menyelesaikan masalah pekerjaan secara rasional/logis dan memberikan kepercayaan sepenuhnya kepada karyawan memberikan tugas sesuai dengan keahlian karyawan.

b. Informan 2 : Pemimpin memberikan kepercayaan dan menghargai ide -ide karyawan, namun wewenang dan tanggung jawab yang diberikan juga berdasarkan jabatan.

c. Informan 3 : Pemimpin mendorong untuk menggunakan kreativitas dalam menyelesaikan pekerjaan, bersemangat untuk mendengarkan ide/gagasan kepada tenaga ahli, memberi tanggung jawab sepenuhnya sesuai dengan keahlian .

2. Dari segi sifat pemimpin :

a. Informan 1 : Pemimpin adalah seorang yang memiliki tujuan yang jelas dan tegas, bisa memberi motifasi kepada bawahan , menumbuhkan rasa percaya diri karyawan dalam melakukan pekerjaan, memberikan sarana prasarana dan fasilitas yang cukup memadai hingga bisa bekerja dengan semangat dan nyaman.

b. Informan 2 : Pemimpin bersifat tegas terutama dalam menentukan keputusan, namun merupakan sosok yang dihormati. Pemimpin berkomunikasi dengan suasana kekeluargaan kepada karyawan, pemimpin juga masuk dalam grub chat disalah satu sosial media di perusahaan dengan tujuan untuk memudahkan komunikasi dan bekerjasama dalam perusahaan, mengadakan syukuran makan bersama pada acara ulang tahun perusahaan, buka bersama, halal bihalal dan lain-lain yang bertujuan agar anggota perusahaan lebih akrab dan lebih mengenali satu dengan yang lain untuk memudahkan kita dalam bekerjasama. Pemimpin memperlakukan pegawai sebagai individu yang masing-masing memiliki kebutuhan, kemampuan, dan aspirasi yang berbeda. Pemimpin memperlakukan karyawan sebagai individu pribadi, bersedia mendengarkan kesulitan dan keluhan yang dialami karyawan, bukan hanya sebagai anggota dari suatu kelompok kerja. Pemimpin memberikan motivasi kepada karyawan, menyediakan fasilitas yang baik, suasana kerja yang nyaman dan mendorong karyawan untuk bekerja lebih baik.

c. Informan 3 : Pemimpin berkomunikasi dengan mudah dan akrab, bawahan tidak merasa takut untuk mengemukakan ide-ide atau masalah pekerjaan. Pemimpin memberikan perhatian kepada bawahan, memberikan fasilitas sarana prasarana yang cukup baik. Pemimpin merupakan sosok yang dihormati walaupun bukan seorang panutan, dan memberikan keyakinan kepada bawahan bahwa tujuan perusahaan akan tercapai. 
Website : http://ekomaks.unmermadiun.ac.id/index.php/ekomaks

3. Dari segi pengambilan keputusan dan kebijakan :

a. Informan 1 : Pemimpin memberi keputusan dan kebijakan yang dirasa penting dan karyawan harus mengikuti keputusan dan kebijakan yang telah diambil.

b. Informan 2 : Dalam situasi tertentu pemimpin memutuskan sesuatu dengan meminta pendapat bawahan, namun dalam hal pesanan pekerjaan atau hal yang dirasa penting pemimpin memutuskan hanya dengan pihak yang terkait dengan perusahaan saja

c. Informan 3 : Dalam kebijakan pengambilan keputusan, pemimpin berwewenang penuh dan memikul tanggung jawab sepenuhnya. Menentukan pekerjaan yang telah diambil dan menetapkan tanggung jawab bagi pelaksanaan pekerjaan kepada pelaksana proyek perusahaan.

4. Dari segi pengarahan bawahan :

a. Informan 1 : Pemimpin memberikan arahan yang jelas tentang apa yang harus karyawan capai karyawan dalam pekerjaan. Pemimpin memberikan sanksi bagi karyawan yang melanggar aturan yang telah ditetapkan dan memberikan reward dengan hasil dan prestasi yang telah karyawan capai dalam pekerjaan

b. Informan 2 : Pemimpin memberi arahan yang tegas atas pekerjaan yang harus karyawan kerjakan dan menyelesaikan masalah dari berbagai sudut pandang. Pemimpin mengajak dan menekankan untuk disiplin dalam segala hal, seperti karyawan harus tertib dan disiplin dalam hal memberikan laporan dan mengontrol laporan dan pekerjaan karyawan , juga harus disiplin dalam hal menaati peraturan-peraturan yang telah ditetapkan oleh perusahaan karena dengan disiplin perusahaan baru bisa maju, pimpinan juga akan menegur setiap karyawan membuat kesalahan.

c. Informan 3 : Pemimpin melakukan komunikasi tentang pekerjaan dengan jelas. Pemimpin mengontrol pekerjaan bawahan dan memberikan nasihat yang sangat penting bagi pengembangan diri bawahan terutama disiplin kerja, manajemen waktu dan lain-lain. Pemimpin memberikan teguran dan sanksi bagi bawahan yang melakukan pelanggaran atau kesalahan dan memberikan penghargaan bagi karyawan yang berprestasi dalam pekerjaannya.

Pembahasan didapatkan dari data ke 3 informan tersebut diatas kemudian di analisis dengan menggunakan indikator yang telah ditentukan maka peneliti menyimpulkan bahwa gaya kepemimpinan yang di terapkan di PT IMSC adalah sebagai berikut: sebagai berikut

\section{IV.KESIMPULAN DAN SARAN}

\section{A. Kesimpulan}

Dari hasil penelitian dapat disimpulkan bahwa :

a. Dalam hal pendelegasian wewenang Gaya Kepemimpinan direktur, termasuk gaya kepemimpinan partisipatif hal ini dikarenakan direktur memberikan wewenang dan tanggung jawab kepada karyawan, namun wewenang dan tanggung jawab yang diberikan juga berdasarkan jabatan.

b. Sifat pemimpin perusahaan, lebih ke gaya kepemimpinan Suportif. Gaya ini menjadikan karyawan merasa nyaman dalam berkomunikasi, Pemimpin juga memperhatikan kenyamanan tempat bekerja dan fasilitas kerja yang memadai. Pimpinan memposisikan diri bukan sebagai bos namun sebagai leader. Pimpinan bisa mendengarkan keluhan dari para pegawai dan mencarikan solusi untuk mereka. Selain itu pimpinan juga membuat suasana yang akrab dan menjadikan semua karyawan bekerjasama dalam sebuah tim yang kuat untuk mencapai target perusahaan

c. Dalam hal pengambilan keputusan dan kebijakan direktur termasuk gaya kepemimpinan Direktif, terbukti karena seringkali pengambilan keputusan dan kebijakan yang dilakukan direktur tidak dengan ide atau pendapat dari karyawan

d. Dalam hal pengarahan bawahan Pemimpin menerapkan gaya kepemimpinan Direktif , terbukti bahwa direktur selalu memberikan perintah atau instruksi kepada bawahan agar disiplin, dan direktur juga memberikan imbalan kepada karyawan yang meraih prestasi sebagai karyawan terbaik dan teguran (hukuman) apabila ada karyawan yang melanggar aturan.

\section{B. Saran}

Direktur sebaiknya sering tatap muka dan berkomunikasi dengan karyawan di level 3, atau berkedudukan di bawah manajer atau kepala bagian, karena karyawan di level 3 merasa tatap muka dengan direktur kurang. Hal ini dapat juga menjadikan karyawan di level 3 merasa nyaman dalam bekerja apabila akrab dengan atasan dan kerjasama juga makin baik apabila sering berkomunikasi atau tatap muka dengan direktur. Dan sebaiknya perusahaan memberikan pelatihan- pelatihan yang sesuai dengan bidang masing-masing serta pelatihan-pelatihan untuk meningkatkan profesionalitas karyawan yang mana hal tersebut bisa meningkatkan kualitas dan produktifitas kerja karyawan yang akan meningkatkan solvabilitas, likuiditas serta rentabilitas perusahaan. 
Website : http://ekomaks.unmermadiun.ac.id/index.php/ekomaks

\section{DAFTAR PUSTAKA}

Amirullah. "Pengatar Manajemen". Mitra Wacana Media, Jakarta, 2015.

Bangun, Wilson. "Manajemen Sumber Daya Manusia".Erlangga. Jakarta, 2012.

Daft, R., (2011). Era Baru Manajemen. Jakarta: Salemba Empat.

Fahmi, Irham. "Manajemen Kepemimpinan Teori dan Aplikasi". Alfabeta, Jakarta, 2014.

Fahmi,Irham, 2012,Manajemen Kepemimpinan Teori dan Aplikasi, Alfabeta,Bandung.

Hartanto, Adrian, Analisis Gaya Kepemimpinan pada PT Sinar Sukses, jurnal Agora Vol.4 No.2 (2016)

Hasibuan, S.P. (2012). Manajemen Sumber Daya Manusia (Edisi Revisi). Jakarta: PT. Bumi Aksara

Sugiyono. (2012). Metode Penelitian Bisnis. Bandung: CV. Alfabeta

Sugiyono. (2013). Metode Penelitian Kuantitatif, Kualitatif, dan R\&D. Bandung: CV. Alfabeta.

Suwatno. "Manajemen Sumber Daya Manusia dalam Organisasi Publik dan Bisnis". Penertbit Alfabeta, Bandung, 2013

Hughes, Richard L., Ginnet, Robert C., Curphy, Gordon J., (2012). Leadership: Enhacing the Lessons of Experience, Seventh Edition. Singapore: Mcgraw Hill Companies.

Kartono, DR. "Pemimpin dan Kepemimpinan". Penerbit Raja Grafindo Persada, Jakarta, 2010

Moleong, L. J. (2013). Metode penelitian kualitatif (Edisi revisi). Bandung : Remaja Rosdakarya.

Sugiyono. (2013). Metode Penelitian Kuantitatif, Kualitatif, dan R\&D. Bandung: CV. Alfabeta.

Suwatno. "Manajemen Sumber Daya Manusia dalam Organisasi Publik dan Bisnis". Penertbit Alfabeta, Bandung, 2013

Thoha, Miftah. (2010) Kepemimpinan dalam manajemen. Cetakan ke 15. Jakarta, Rajawali Press 